\title{
Gutt med sår på fingeren som ikke ville gro
}

\author{
Behandlingsrefraktært sår hos barn kan ha mange årsaker. Tilstanden \\ krever grundig utredning når de vanligste årsakene er utelukket.
}

En gutt i starten av tenårene oppsøkte fastlegen på grunn av en vorteliknende forandring med fortykket hud distalt på høyre langfinger, der det etter hvert var blitt en blodfylt blemme. Pasienten hadde alltid vært frisk, var $i$ god allmenntilstand og hadde verken feber, vekttap eller nattesvette. Hos fastlegen ble blemmen drenert, og det ble forsøkt sårbehandling med Flamazine-smokk.

Da fingeren ikke ble bedre, ble han henvist til ortopedisk avdeling ved lokalsykehuset. Såret ble revidert, og etter prøvetaking til mikrobiologisk diagnostikk ble det startet antibiotikabehandling med dikloksacillin. Det var ingen oppvekst av bakterier eller virus. Biopsi viste reaktive forandringer. Røntgenbilde av høyre hånd viste erosjon av distale falang på 3. finger. Det var ingen andre funn i skjelettet.

Echtyma contagiosum, sauekopper eller orfvirussykdom (Melkerssons noduli), som smittes fra sau/kyr, ble diskutert som mulig diagnose. Gutten hadde besøkt en dyrepark, men ellers ikke vært i kontakt med dyr.

Tilstanden ble verre, og omtrent fire måneder etter symptomdebut ble pasienten henvist til hudlege ved lokalsykehuset og videre til hudavdelingen ved universitetssykehus. Ved innleggelsen var gutten fortsatt i god form, afebril og ikke infeksjonspreget.

Blodprøver viste hemoglobin $14, \mathrm{lg} / 100 \mathrm{ml}$ $(11,7-15,3 \mathrm{~g} / 100 \mathrm{ml}$, leukocytter 4,3 $10 \% / \mathrm{l}$ $\left.\left(3,6-9,3 \cdot 10^{9} / \mathrm{l}\right), C R P<0,6 \mathrm{mg} / \mathrm{l} /<4 \mathrm{mg} / \mathrm{l}\right)$ og senkning $2 \mathrm{~mm}(1-17 \mathrm{~mm})$. Ved undersøkelse fant man en svart nekrotisk og blødende tumor i distale falang, moderat negledystrofi og tegn til trommestikkfinger (clubbing) (fig 1). Pasienten hadde økende smerter $i$ fingeren og ble vurdert av infeksjonsmedisiner og håndkirurg.

Flere diagnoser ble diskutert. Fra et dermatologisk ståsted passet pyogent granulom godt med lokaliseringen, men det gir vanligvis ikke nekrose. Neoplasi ble vurdert som mindre sannsynlig ut fra lokalisering og alder. Infeksjonsmedisiner overveide infeksjon med atypiske mykobakterier. Sirkulatoriske forandringer ble utelukket av håndkirurgen.

Det ble tatt nye mikrobiologiske prøver, ny undersøkelse av finger og hånd. Gutten ble utskrevet fra hudavdelingen i påvente av resultatet fra den nye biopsien. Røntgen viste destruksjon ytterst $i$ ytterfalangen (fig 2). MR viste en bløtdelsoppfylling ytterst på 3. finger som målte $15 \times 15 \times 18 \mathrm{~mm}$. Det var infiltrasjon $i$ hud og beinmargsødem $i$ resten av ytterfalangen (fig 3). Den nye biopsien viste tallrike blodkar og epitel med mye granulocytter. Det var ingen tegn til mitoser eller neoplasi.

Håndkirurgen anbefalte å ta kontakt med ortoped i sarkomgruppen. MR-bilder ble oversendt sammen med biopsiene som var tatt ved universitetssykehus og lokalsykehus. Bildene ble vurdert av radiolog og ortoped $\mathrm{i}$ biopsi i ledningsanestesi og røntgen-og MR-

\section{Ivar Hompland}

ivar.hompland@ous-hf.no Avdeling for kreftbehandling Oslo universitetssykehus, Radiumhospitalet

Syed Mohammad Husain Rizvi

Seksjon for hudsykdommer

Oslo universitetssykehus, Rikshospitalet

\section{Mona Winge}

Seksjon for overekstremitets- og mikrokirurgi Ortopedisk avdeling

Oslo universitetssykehus, Rikshospitalet

\section{Ole-Jacob Norum}

Seksjon for onkologisk ortopedi

Ortopedisk avdeling

Oslo universitetssykehus, Radiumhospitalet

\section{Bodil Bjerkehagen}

Seksjon for barnekreft, øre-nese-hals, sarkom, nevro og hematopatologi.

Avdeling for patologi

Oslo universitetssykehus, Radiumhospitalet

\section{Hanne Osnes Ringen}

Seksjon for overekstremitets- og mikrokirurgi Ortopedisk avdeling

Oslo universitetssykehus, Rikshospitalet

\section{Ingeborg Taksdal}

Enhet for onkologisk radiologi

Avdeling for radiologi og nukleærmedisin

Oslo universitetssykehus, Radiumhospitalet

\section{Nils-Jørgen Mørk}

Seksjon for hudsykdommer

Oslo universitetssykehus, Rikshospitalet

Kirsten Sundby Hall

Avdeling for kreftbehandling

Oslo universitetssykehus, Radiumhospitalet
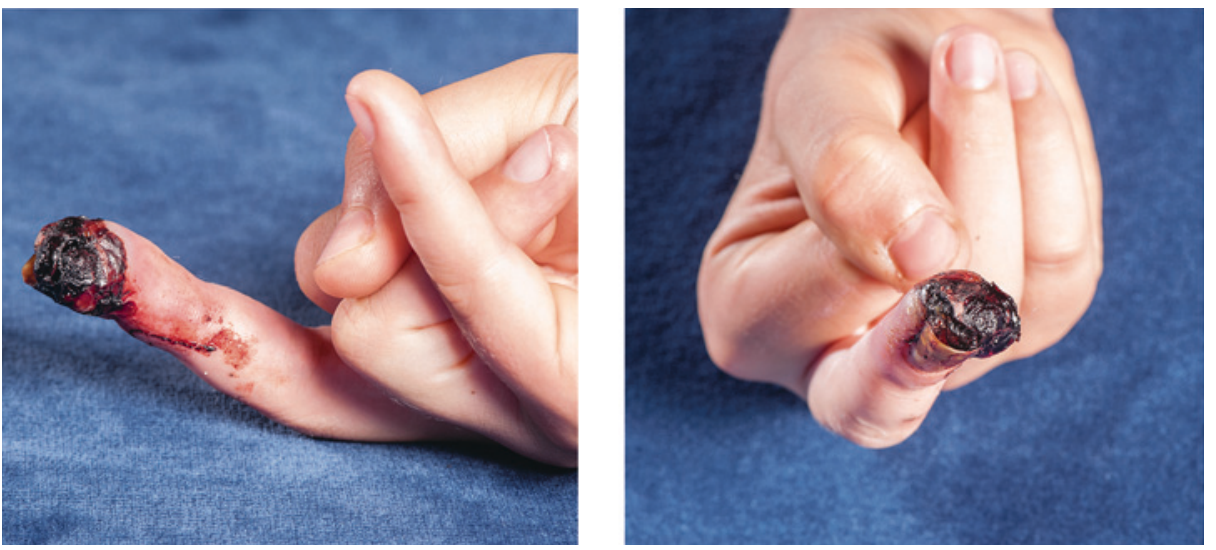

Figur 1 Ved ankomst universitetssykehuset, omtrent fire måneder etter symptomdebut, så fingeren slik ut. Foto: Øystein H. Horgmo, Universitetet i Oslo 


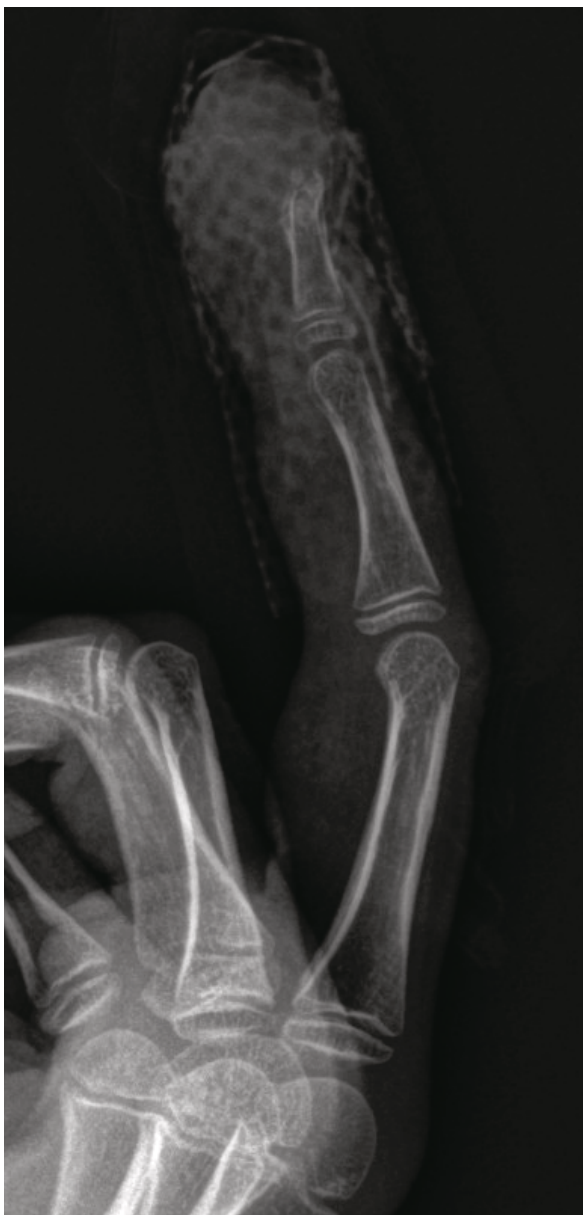

Figur 2 På røntgen av 3. finger i sideplan ses beindestruksjon i distale falang og bløtdelshevelse IOBS bandasjel

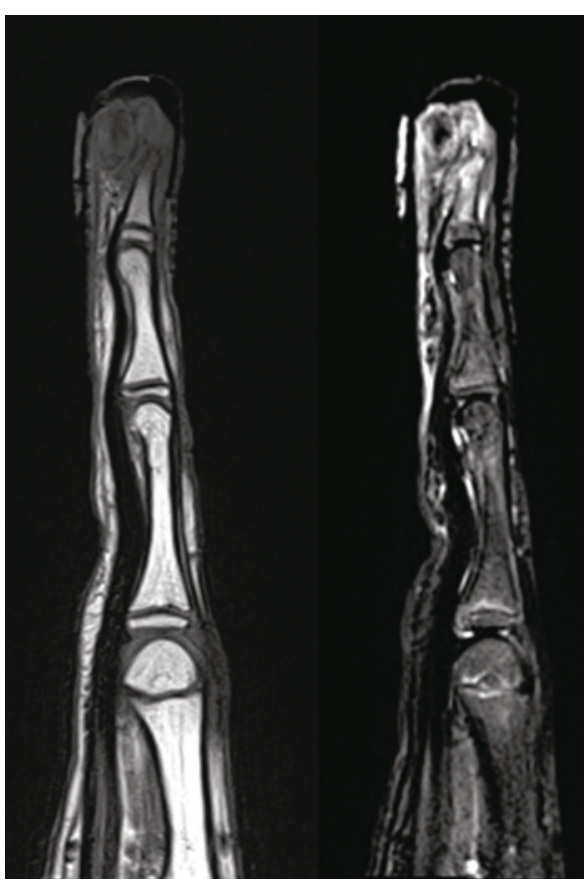

Figur 3 MR av 3. finger, sagittal T1 og STIR. Det ses bløtdelsoppfylling, tumorinfiltrasjon ytterst i ytterfalangen og beinmargsødem sarkomgruppen. Vurderingen var at situasjonen var mest forenlig med en inflammatorisk tilstand. Biopsier fra både lokalsykehuset og universitetssykehuset ble vurdert av sarkompatolog, uten at det ble påvist malignitet. Ny og dypere biopsi ble anbefalt.

En uke etter utskrivning fra hudavdelingen ble gutten innlagt ved håndkirurgisk avdeling ved universitetssykehuset for videre utredning og behandling. Da det ikke var noen bedring av tilstanden, ble amputasjon eller ny og dypere biopsi diskutert med pasienten og hans foresatte. Gutten ønsket, hvis mulig, å beholde fingeren.

Det ble så i narkose tatt dyp sylinderbiopsi $16 \mathrm{~mm}$ i diameter) fra tumoren, med materiale fra både bløtvev og bein. Biopsien viste epiteloide og spolformede celler med lav mitoseaktivitet (fig 4). Immunhistokjemisk undersøkelse viste positiv reaksjon for $A E 1 /$ AE3, EMA, CD 34, CD99 og CK19.

Samlet passet dette med epiteloid sarkom. Nå overtok sarkomgruppen videre utredning.

Det ble gjort metastaseutredning med CT thorax, som ikke viste metastaser til lungene, men to lett markerte lymfeknuter $i$ høyre aksille. Ultralydundersøkelse av begge aksiller med cytologisk prøve fra den ene lymfeknuten viste ikke maligne celler. I tillegg ble ultralydundersøkelse av hele høyre overekstremitet og MR hånd og distale underarm utført, uten at det var tegn til metastaser.

Seks måneder etter utredningsstart ble pasienten operert av tumorortopedene, med amputasjon i proksimale interfalangealledd. Operasjonspreparatet viste epiteloid sarkom. Tumoren var $7 \times 5 \mathrm{~mm}$ stor og hadde diffust infiltrerende vekstmåte, uten karinfiltrasjon, og det var frie reseksjonsflater med god margin.

Pasienten ble diskutert på tverrfaglig sarkommøte. Epiteloid sarkom er generelt en lite cytostatikafølsom tumor, og det var ikke indikasjon for adjuvant kjemoterapi (1). Postoperativ strålebehandling var ikke nødvendig, da pasienten var amputert med god margin $(2,3)$.

Gutten skal kontrolleres ved universitetssykehuset i ti år med henblikk på lokal status, regionale lymfeknuter og lungemetastaser (røntgen thorax). Kontrollene skal utføres hver tredje måned de første tre årene, deretter hver fjerde måned til det er gått fem år, og så halvårlig de siste fem årene.

\section{Diskusjon}

Gutten var en diagnostisk utfordring. Han ble først vurdert hos fastlegen, som henviste ham til lokalsykehus, deretter ble han vurdert av lokal hudlege. Etter hvert ble han henvist regionsykehus. Diagnosen epiteloid sarkom ble stilt etter seks måneder. På grunn av tumors initialt uskyldige utseende blir den ofte diagnostisert sent. de Visscher og medarbeidere gjennomgikk flere studier og påviste en diagnostisk forsinkelse på 7-30 måneder (4).

Epiteloid sarkom er en sjelden form for bindevevskreft $(<1 \%$ av bløtvevssarkomene), først beskrevet av Enzinger i 1970 (5). Litteraturen består av kasuistikker og små pasientkohorter (6). Sykdommen rammer som oftest unge menn (3-4:1) i 20-, 30- og 40-årene. Den affiserer ekstremitetene, særlig hender, fingre, underarmer, legger og føtter, og er det hyppigst forekommende bløtvevssarkom $i$ hånden (7). Andre lokaliseringer som penis, perineum og vulva er sjeldne (4).

Siden 1970 er 23 pasienter med epiteloid sarkom behandlet ved Oslo universitetssykehus - sju kvinner og 16 menn, med en gjennomsnittsalder på 38 år. Dette ifølge Kvalitetsregister for sarkomer ved sykehuset, som inneholder totalt 4074 bløtvevssarkomer (8).

Vanligvis fremstår epiteloide sarkomer som faste, hudfargede, indolente knuter. De kan ulcerere og affisere subcutis og dypere bindevev som muskelfascie og sener. Histologisk har epiteloide sarkomer nodulært vekstmønster og viser både epitelial og mesenkymal differensiering. Tumor mistolkes ofte som en kronisk inflammatorisk prosess, nekrotiserende granulom eller fibrohistiocyttære tumorer $(9,10)$.

Epiteloide sarkomer kan deles inn i to kliniskpatologiske typer - proksimal type og klassisk (distal) type. Proksimal type er assosiert med dårligere prognose, den har store celler med rabdoide trekk og er oftest lokalisert på truncus og proksimalt i ekstremitetene. Den klassiske typen har et granulomaktig utseende og er oftest lokalisert distalt i ekstremitetene $(11,12)$.

Det er en tendens til at epiteloide sarkomer metastaserer lokalt, som oftest via lymfesystemet eller langs fascier. Som for andre bløtvevssarkomer er lungene det vanligste stedet for fjernmetastaser (12). Negative prognostiske faktorer er dyptliggende tumor, lymfeknute- og/eller fjernmetastaser på diagnosetidspunktet, proksimal lokalisering og histologiske faktorer som ufri rand, nekrose og vaskulær invasjon. Ung alder, distal lokalisasjon og kvinnelig kjønn er assosiert med bedre prognose (13).

Behandlingsprinsippene er som for andre typer bløtvevssarkomer: Kirurgi med god margin til tumor. Undersøkelse av regionale lymfeknuter bør gjøres $(7,13)$. Ved ufri rand blir det gitt strålebehandling, men effekten er ikke godt dokumentert $(2,3)$. Cytostatika har en usikker plass i behandlingen (1). 


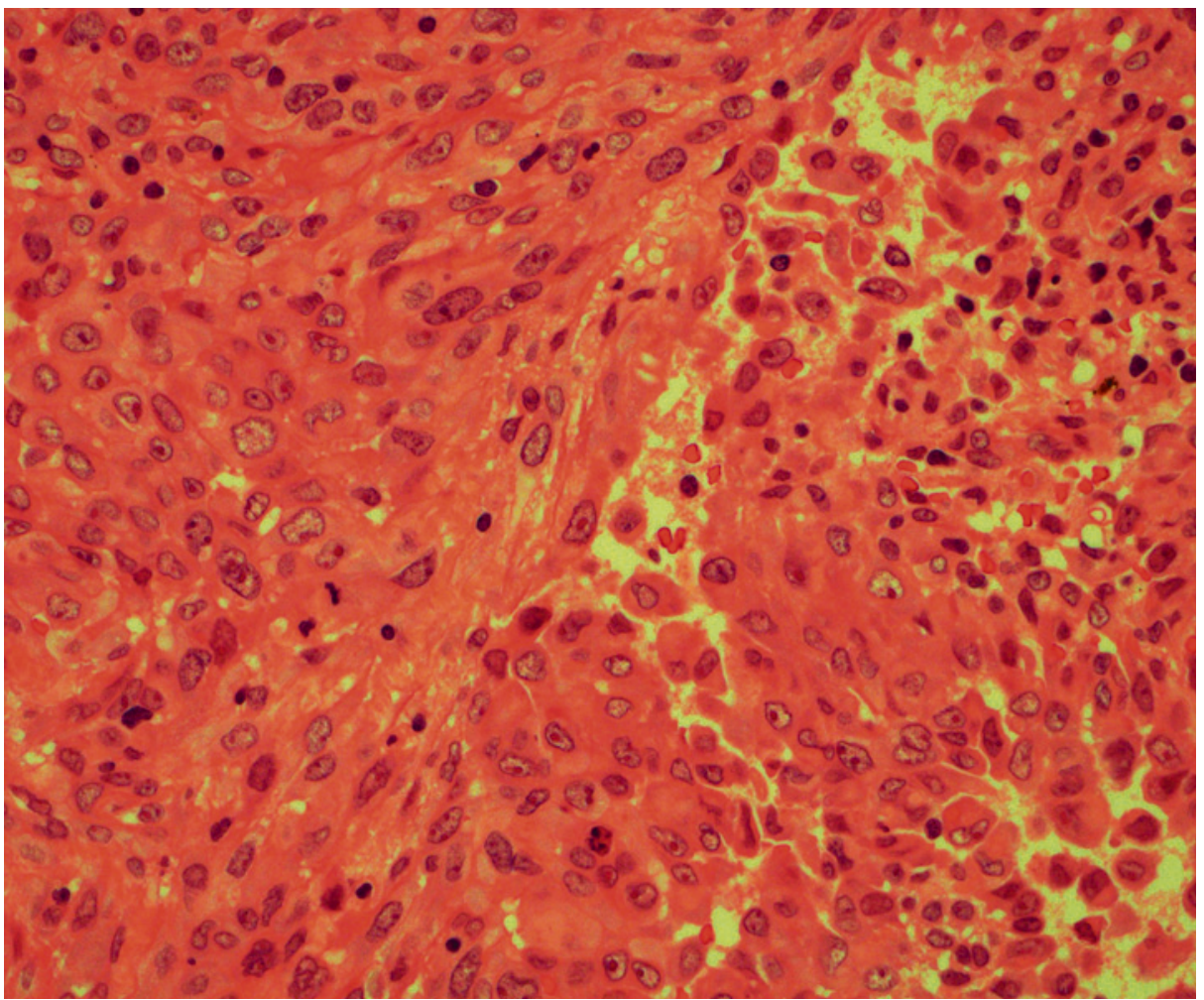

Figur 4 Mikroskopisk undersøkelse viser spolformede celler med runde eller ovale kjerner med tydelig kjernemembran og nukleol. Immunhistokjemisk analyse viste positivt funn for antistoffet AE1/AE3

I litteraturen er det variasjoner i femårs og tiårs totaloverlevelse. En femårsoverlevelse på $60-75 \%$ er rapportert. Flere studier har vist at lokalresidiver og metastaser kan komme sent i forløpet - tiårsoverlevelsen er betydelig dårligere, ned mot $30 \%$ (4-7).

Hos den unge gutten startet tilstanden med en liten, indolent knute som etter hvert utviklet seg til et sår som ikke ville gro. Ved sår som ikke gror er det viktig å vurdere underliggende årsaker, for eksempel malignitet. Mikrobiologiske prøver og biopsier bør tas. Hos vår pasient ble det tatt tre biopsier før den endelige diagnosen ble stilt. Kanskje det tidligere burde vært tatt dypere biopsi i narkose? Det ville sannsynligvis gitt større mulighet for å få et representativt materiale.

Vi synes det er vanskelig å gi klare retningslinjer for håndtering av et så spesielt tilfelle og vil minne om at ved mistanke om bløtvevssarkom har Skandinavisk sarkomgruppe (SSG) vedtatt kliniske retningslinjer for hvilke pasienter med ekstremitets- og truncuslokaliserte tumorer som skal henvises til spesialavdeling uten forutgående operasjon eller invasiv diagnostikk. Det gjelder alle dype tumorer uansett størrelse (immobile mot kontrahert muskulatur) og alle subkutane tumorer $>5 \mathrm{~cm}$ (14).

Ved en klinisk suspekt tumor er MRundersøkelse velegnet til fremstilling av

\section{Syed Mohammad Husain Rizvi (f. 1983)}

er lege i spesialisering i hud-og veneriske sykdommer.

Forfatter har fylt ut ICMJE-skjemaet og oppgir ingen interessekonflikter.

\section{Mona Winge (f. 1969)}

er spesialist i ortopedi og overlege. Forfatter har fylt ut ICMJE-skjemaet og oppgir ingen interessekonflikter.

\section{Ole-Jacob Norum (f. 1969)}

er spesialist i ortopedisk kirurgi, med spesialkompetanse i kreftortopedi, og seksjonsleder. Forfatter har fylt ut ICMJE-skjemaet og oppgir ingen interessekonflikter.

\section{Bodil Bjerkehagen (f. 1959)}

er spesialist i patologi, med spesialkompetanse i bløtvevs- og beinsvulster, og seksjonsleder. Hun er leder for patologigruppen i Skandinavisk sarkomgruppe.

Forfatter har fylt ut ICMJE-skjemaet og oppgir ingen interessekonflikter.

\section{Hanne Osnes-Ringen (f. 1972)}

er ph.d., spesialist i ortopedisk kirurgi og overlege.

Forfatter har fylt ut ICMJE-skjemaet og oppgir ingen interessekonflikter.

\section{Ingeborg Taksdal (f. 1959)}

er spesialist i radiologi, med spesialkompetanse i bein- og bløtvevssvulster. Forfatter har fylt ut ICMJE-skjemaet og oppgir ingen interessekonflikter. lipomer fra andre typer bløtvevssvulster. Subkutane lipomer kan behandles utenfor tumorsenter. Ved hjelp av cytologisk prøve kan man også identifisere lipomer ved klinisk overflatisk lesjon.

\section{Konklusjon}

Studier viser at det ofte kan ta lang tid før diagnosen blir stilt ved epiteloid sarkom (3). I dette tilfellet tok det et halvt år fra gutten fikk symptomer til han ble operert. Som ved de fleste andre typer sarkom er det viktig for prognosen at diagnosen blir stilt tidlig. Denne pasienthistorien viser at god tverrfaglig diskusjon mellom forskjellige spesialiteter er av stor betydning for å sikre korrekt diagnose og behandling.

Pasienten og hans foresatte har gitt samtykke til at artikkelen blir publisert

\section{Ivar Hompland (f. 1982)}

er lege i spesialisering i onkologi og konstituert overlege.

Forfatter har fylt ut ICMJE-skjemaet og oppgir ingen interessekonflikter.

\section{Nils-Jørgen Mørk (f. 1950)}

er spesialist i hud-og veneriske sykdommer og seksjonsoverlege.

Forfatter har fylt ut ICMJE-skjemaet og oppgir ingen interessekonflikter.

\section{Kirsten Sundby Hall (f. 1951)} tanse i sarkomer, og overlege. Hun er leder for sarkomprogrammet ved Radiumhospitalet og for Skandinavisk sarkomgruppe.

Forfatter har fylt ut ICMJE-skjemaet og oppgir ingen interessekonflikter.

\section{Litteratur}

1. Jones RL, Constantinidou A, Olmos D et al. Role of palliative chemotherapy in advanced epithelioid

2. Shimm DS, Suit HD. Radiation therapy of epithelioid sarcoma. Cancer 1983; 52: 1022-5.

3. Callister MD, Ballo MT, Pisters PWT et al. Epithelioid sarcoma: results of conservative surgery and radiotherapy. Int J Radiat Oncol Biol Phys 2001: 51:384-91.

4. de Visscher SAHJ, van Ginkel RJ, Wobbes T et al. Epithelioid sarcoma: Still an only surgically curable disease. Cancer 2006; 107: 606-12.

5. Enzinger FM. Epitheloid sarcoma. A sarcoma simulating a granuloma or a carcinoma. Cancer 1970: 26: 1029-41. er spesialist i onkologi, med spesialkompesarcoma. Am J Clin Oncol 2012; 35: 351-7. 
6. Raabe N, Solheim O, Stenwig AE et al. Epiteloid sarkom. Tidsskr Nor Lægeforen 1987; 107: 2748-51.

7. Spillane AJ, Thomas JM, Fisher C. Epithelioid sarcoma: the clinicopathological complexities of this rare soft tissue sarcoma. Ann Surg Oncol 2000; 7: 218-25.

8. Kvalitetsregister for sarkomer, Oslo universitetssykehus. www.sarkomer.no (17.12.2014).

9. Sakharpe A, Lahat G, Gulamhusein T et al. Epithelioid sarcoma and unclassified sarcoma with epithelioid features: clinicopathological variables, molecular markers, and a new experimental model. Oncologist 2011; 16: 512-22.

10. Modena P, Lualdi E, Facchinetti F et al. SMARCB1/ INI1 tumor suppressor gene is frequently inactivated in epithelioid sarcomas. Cancer Res 2005; 65: 4012-9.

11. Hasegawa T, Matsuno Y, Shimoda T et al. Proximal-type epithelioid sarcoma: a clinicopathologic study of 20 cases. Mod Pathol 2001: 14: 655-63.

12. Guillou L, Wadden C, Coindre JM et al. «Proximaltype» epithelioid sarcoma, a distinctive aggressive neoplasm showing rhabdoid features. Clinicopathologic, immunohistochemical, and ultrastructural study of a series. Am J Surg Pathol 1997; 21: $130-46$.

13. Chase DR, Enzinger FM. Epithelioid sarcoma. Diagnosis, prognostic indicators, and treatment. Am J Surg Pathol 1985; 9: 241-63.

14. Treatment protocols and recommendations Sarcoma. www.ssg-org.net/treatment-protocolsand-recommendations/ongoing (1.11.2014).

Mottatt 11.6. 2014, første revisjon innsendt 2.12. 2014, godkjent 17.12. 2014. Redaktør: Hanne Støre Valeur. 